\title{
Molecular cloning, identification and characterization of four distinct receptor subtypes for insulin and IGF-I in Japanese flounder, Paralichthys olivaceus
}

\author{
N Nakao, M Tanaka, Y Higashimoto and K Nakashima \\ Department of Biochemistry, Faculty of Medicine, Mie University, Mie 514-8507, Japan \\ (Requests for offprints should be addressed to K Nakashima)
}

\begin{abstract}
Insulin receptor (IR) and IGF-I receptor (IGF-IR) are structurally and functionally related and belong to the tyrosine kinase receptor family. In teleosti such as salmonids and turbot, occurrence of multiple IR and IGF-IR members has been reported, but the structures of a complete set of both IR and IGF-IR members in a single teleost species have not yet been characterized. In this study, we cloned and analysed four distinct cDNA clones for IR and IGF-IR members from the liver and kidney of the Japanese flounder (Paralichthys olivaceus). Deduced amino acid sequence analyses and phylogenetic analysis have revealed that two of them (fIR-1 and flR-2) belong to IR members and the other two (flGF-IR-1 and flGF-IR-2) are IGF-IRs. fIR-1 and flR-2 comprised 1369 and 1368 amino acid residues respectively, and flGF-IR-1 and flGF-IR-2 comprised 1412 and 1418 residues respectively. All the receptor proteins contained
\end{abstract}

cysteine-rich domains in their $\alpha$-subunits, and conserved each transmembrane and tyrosine kinase domains in their $\beta$-subunits. The amino acid sequences of flRs and flGFIRs showed more than $90 \%$ sequence identity with turbot IR and IGF-IR respectively. When compared with their mammalian homologues, flGF-IR-1 and flGF-IR-2 proteins contained large insertions at their C-termini, as was observed in the corresponding region of turbot IGF-IR. Occurrence of multiple species of mRNA for each IR and IGF-IR was suggested by Northern blot analyses. A ribonuclease protection assay revealed diverse expressions of four receptor mRNAs in a wide range of tissues including heart, liver, ovary, testis, brain, gill arch, kidney, skeletal muscle, intestine, stomach, spleen and eye of the flounder.

Journal of Endocrinology (2002) 173, 365-375

\section{Introduction}

Insulin receptor (IR) and insulin-like growth factor-I receptor (IGF-IR) are members of the tyrosine kinase receptor family (Ebina et al. 1985, Ullrich et al. 1985, 1986, Hanks et al. 1988). These two receptors are composed of two $\alpha$ - and two $\beta$-subunits linked by disulphide bonds, forming $\alpha 2 \beta 2$ heterodimers. The $\alpha$-subunits compose their extracellular domains and possess the cysteinerich ligand-binding sites. The $\beta$-subunits contain single transmembrane domains and highly conserved cytoplasmic tyrosine kinase domains (Cheatham \& Kahn 1995, LeRoith et al. 1995). In teleosts, ligand-binding studies using mammalian IGF-I and insulin have consistently demonstrated the presence of high-affinity binding sites on various membranes prepared from teleost tissues (Drakenberg et al. 1993, Párrizas et al. 1995, Maestro et al. 1997). The binding of IGF-I in teleost muscle ectotherms was abundant and at higher affinity than that of insulin, although IGF-IR mRNA was expressed at the lowest levels in rainbow trout muscle (Greene \& Chen 1999a,b).
However, in birds and mammals, the situation is reversed, suggesting functional changes in insulin and IGF-I during evolution (Gutierréz et al. 1995).

Insulin and IGF-I show overlapping effects in the growth promotion of teleosti (Kelley et al. 1993, Cheng \& Chen 1995), but the mechanisms of their receptormediated signal transductions are largely unknown. In tetraploid salmonids, multiple IR and IGF-IR species have been identified by cDNA cloning. Chan et al. (1997) have suggested the presence of four IR and two IGF-IR mRNA species in the salmon by cloning partial cDNAs for their regions of the tyrosine kinase domain. In rainbow trout, three IR and two IGF-IR cDNA clones have been isolated (Greene \& Chen 1999a,b), although these clones do not encode full lengths of each protein. Recently, one cDNA clone encoding a partial amino acid sequence of turbot IR and another clone encoding the full sequence of turbot IGF-IR have been reported (Eliès et al. 1999). For understanding the distinct or common physiological functions of insulin and IGF-I in teleosts, it is essential to elucidate the complete structures of all IR and IGF-IR 
Table 1 Primer sequences used in the cDNA cloning

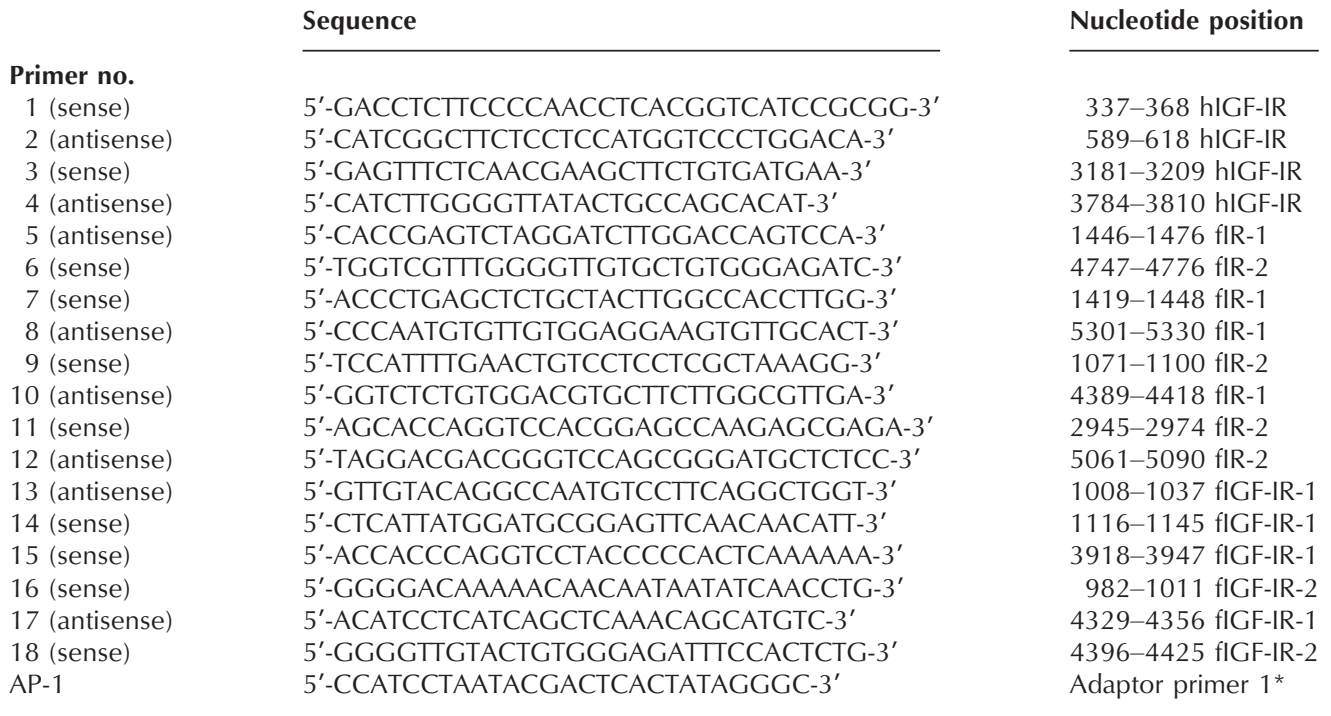

hIGF-IR, human IGF-IR; * Marathon cDNA Adaptor primer 1.

species in a single teleost species. In the present study, we have cloned and characterized the complete set of cDNA for IR and IGF-IR (two IRs and two IGF-IRs) and analysed their tissue distribution in a diploid fish, Japanese flounder (Tabata 1991).

\section{Materials and Methods}

\section{Animals}

Sexually matured male and female Japanese flounders (Paralichthys olivaceus), weighing 700-900 g, 15 months of age, were purchased from a local fish farm (Yada Suisan, Suzuka, Japan). At the time of the experiment, it was observed that the gonads were fully developed in both sexes. The liver, spleen, stomach, intestine, testis, ovary, kidney, skeletal muscle, brain, heart, gill arch and eye were quickly removed from the fish and immediately frozen in liquid nitrogen and kept at $-80{ }^{\circ} \mathrm{C}$ until use.

\section{RT-PCR and $c D N A$ cloning}

Total RNA was extracted from tissues of Japanese flounders by the acid guanidinium-phenol-chloroform method (Chomczynski \& Sacchi 1987) and poly(A)+ RNA was isolated with Oligotex-dT30 (Takara, Tokyo, Japan). cDNA libraries were prepared from liver and kidney poly(A)+ RNAs with a Marathon cDNA amplification kit (Clontech, Palo Alto, CA, USA), and IR and IGF-IR cDNAs were amplified by PCR with sense and antisense primers (Table 1) derived from the human IGF-IR cDNA (Ullrich et al. 1986). The $5^{\prime}$ - and $3^{\prime}$-regions of IR and
IGF-IR cDNAs were synthesized by the rapid amplification of cDNA ends method. The amplified cDNA fragments were cloned into pGEM-T Easy Vector (Promega, Madison, WI, USA) and sequenced by the dideoxy chain-termination method (Sanger et al. 1977).

\section{Ribonuclease (RNase) protection assay}

Appropriate cDNA fragments for flounder IR-1 (flR-1), fIR-2, flGF-IR-1 and flGF-IR-2 were synthesized by PCR and cloned into pGEM-T EASY vector. The antisense RNA probes were synthesized by using SP6 and T7 RNA polymerases and $\left[\alpha-{ }_{-32} \mathrm{P}\right] \mathrm{CTP}$. The RNA probes $\left(5 \times 10^{4}\right.$ c.p.m./assay) were hybridized with $20 \mu \mathrm{g}$ total RNA at $50^{\circ} \mathrm{C}$ for $16 \mathrm{~h}$ in $30 \mu \mathrm{l}$ of the solution containing $40 \mathrm{mM}$ Pipes ( $\mathrm{pH}$ 6.5), 0.4 M NaCl, $1 \mathrm{mM}$ EDTA and $80 \%$ formamide. The samples were digested with RNase A $(40 \mu \mathrm{g} / \mathrm{ml})$ and RNase T1 $(2 \mu \mathrm{g} / \mathrm{ml})$ at $37^{\circ} \mathrm{C}$ for $30 \mathrm{~min}$ and then incubated with proteinase $\mathrm{K}(50 \mu \mathrm{g} / \mathrm{ml})$ at $37^{\circ} \mathrm{C}$ for $15 \mathrm{~min}$. The RNA fragments protected from RNase digestion were separated by electrophoresis on a $6 \%$ polyacrylamide $-7 \mathrm{M}$ urea gel and detected by autoradiography. The radioactivity of the protected fragments was analysed with a BAS1000 imaging analyser (Fuji Photo Co., Tokyo, Japan).

\section{Northern blot analysis}

Poly(A)+ RNA $(4 \cdot 5 \mu \mathrm{g})$ isolated from flounder heart was separated by electrophoresis on a $1.0 \%$ agarose gel containing $2 \cdot 2 \mathrm{M}$ formaldehyde and transferred to GenScreen membranes (New England Nuclear, Boston, MD, USA). 
fIR-1

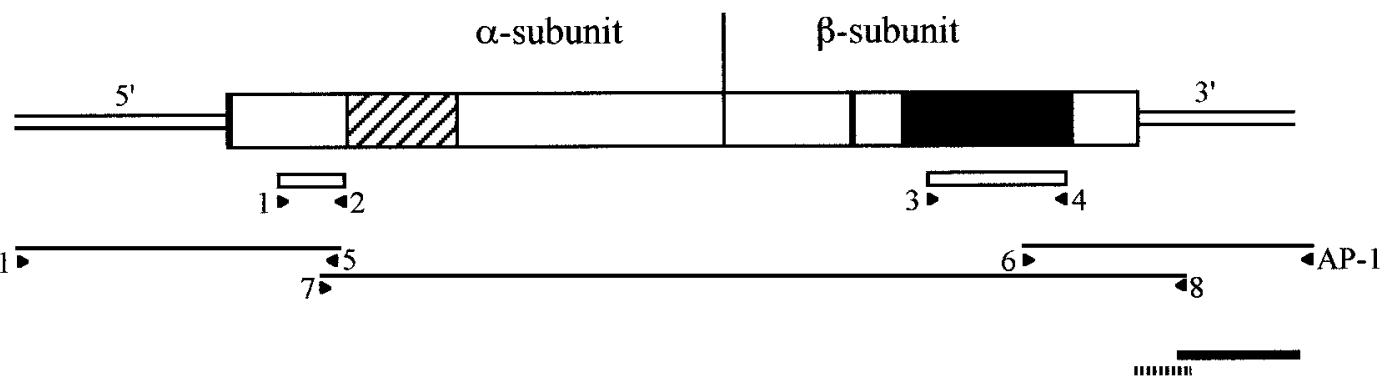

fIR-2

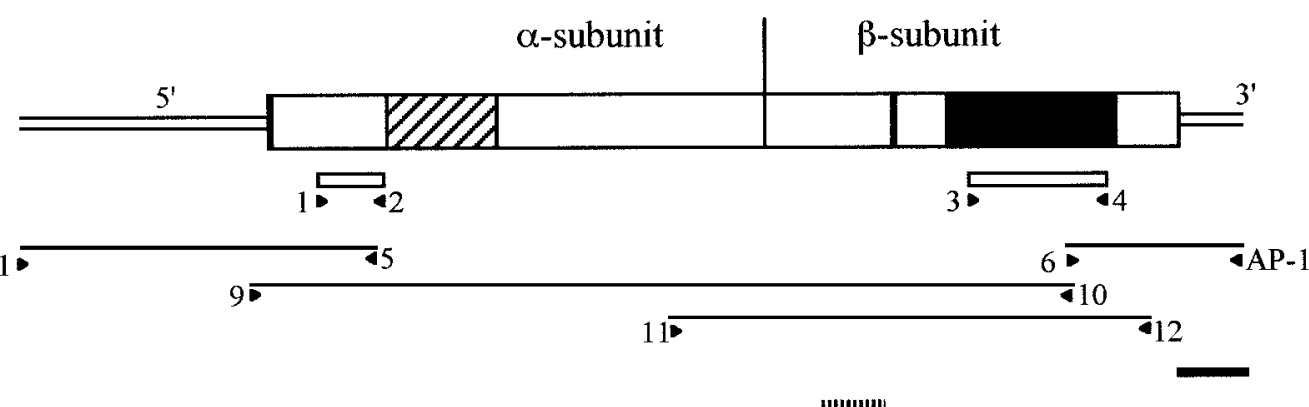

fIGF-IR-1

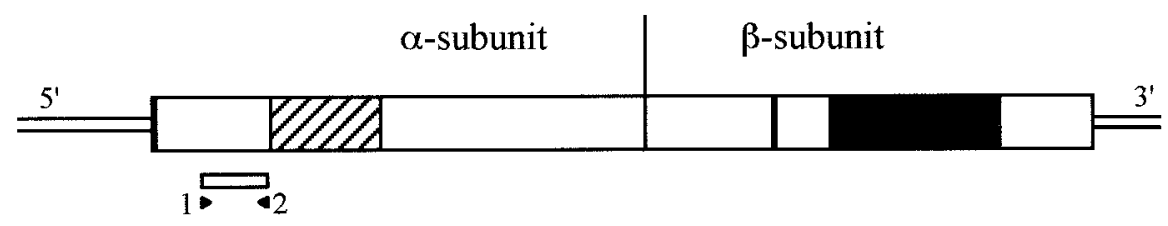

AP-1

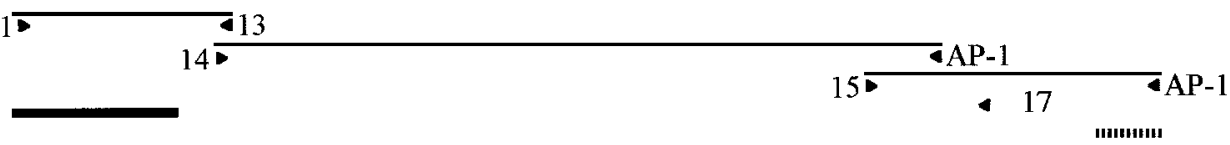

\section{flGF-IR-2}

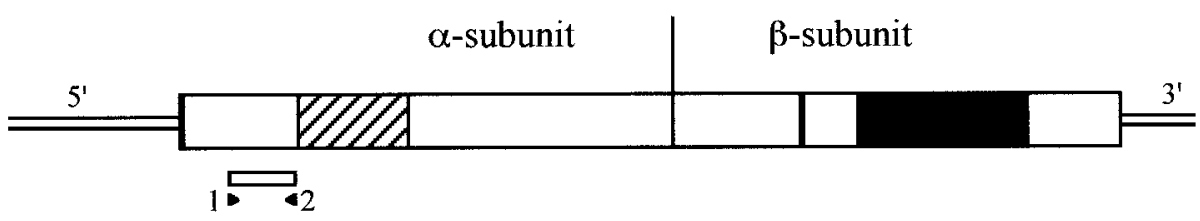

AP-1

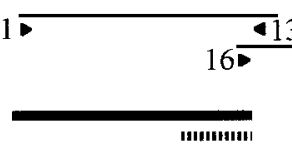

17

$1 8 \longdiv { 4 } + 1 7 - 1$

Figure 1 Schematic representation of the cDNA structures of the flounder Irs (fIR-1 and fIR-2) and IGF-Irs (fIGF-IR-1 and fIGF-IR-2). The boxes indicate the coding regions, and double lines mark the $5^{\prime}$ - and $3^{\prime}$-non-coding regions. The signal sequence is shown by a dark band at the $5^{\prime}$-end of the coding region, the cysteine-rich domain by cross-hatching, the transmembrane domain by a vertical thick bar, and the tyrosine kinase domain by a black box. The thin horizontal lines indicate the cDNA clones isolated. The closed arrowheads show the position of the primers used for PCR. The thick horizontal lines show the probes used for Northern blot analysis. The broken lines show the regions used for the RNase protection assay. The nucleotide sequence of each cDNA will appear in EMBL, GenBank and DDBJ with Accession numbers; fIR-1: AB065096, fIR-2: AB065097, fIGF-IR-1: AB065098, fIGF-IR-2: AB065099. 
(a) fIR-1 1 --MRRWTLKLRAQLVFFIICTCIICOCGEINGEICPSKDIRNNVT"TLQSLENCTIIEGHLK ILIMFKTKAEDFRGLSYPKLRVVTDYVLLFRVYGLEMLS

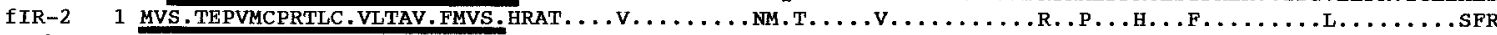
Turbot 1

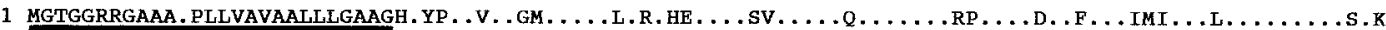

fIR-1

fIR-2

Turbot ELFPNLTVIRGNNLFFNYALVIYEMLQLKEVGFYSLMNITRGAVRIEKNPELC D. . . . . . . . . . . . . . . R. I.LH. . . . . . . . D.

Human D........ SR. . . . . . F. . VH. . L.L.N. . . . . . . . . . . .

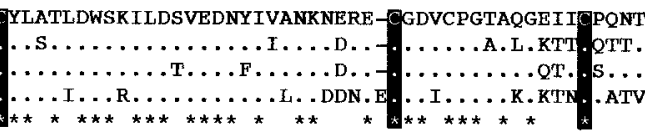

fIR-1

fIR-2

Turbot

Humarı
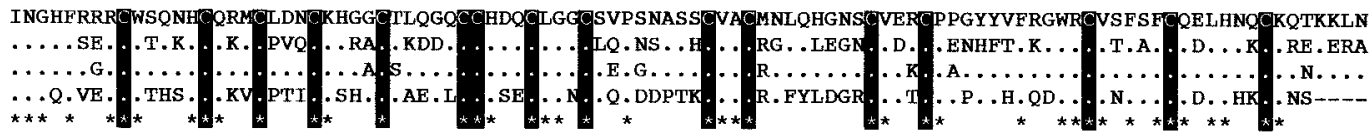

fIR-1

fIR-2

Turbot

QDRELSCNEYVIHNGACIPECPSGYTTINSTTLACSPCAGLCPKLCVGN---KTIDSVNSAQALRGCTVLHGNMIIKIRGGNNIAAELEASLGQLEE ITG

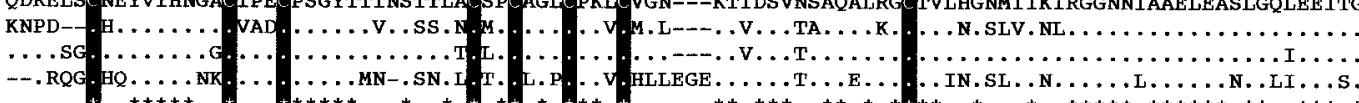

fIR-1

YLTVRRAYALVSLS FLRKLRIIRGEHLETDVHAFYALDNQNLRELWDWSKHNLTILRGRMFFHYNSKLCMSEIRKMEEVTGTKDRNQKNGIAVRNNGDQA

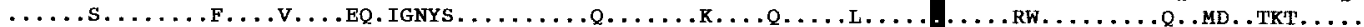

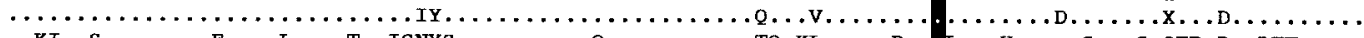

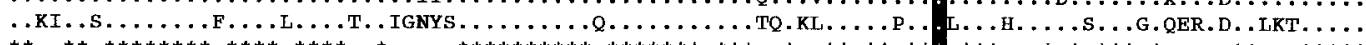

fIR-1

fIR-2

Turbot

Human

EIR-1

fIR-2

Turbot

Human

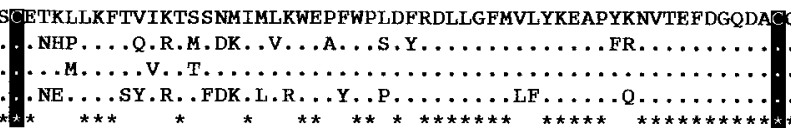

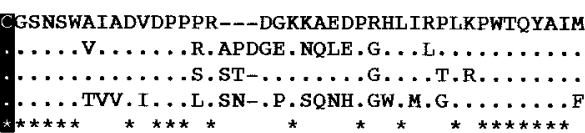

VKTQLSASDEHQVHGAKSE IIYVRTNASKPSVPLDP ISSSNSSSQI ILKWKPPTSPNGNTTHYRVICRKQPEDSDLYKFDYCLQGMELPSRTP-PTWTVR

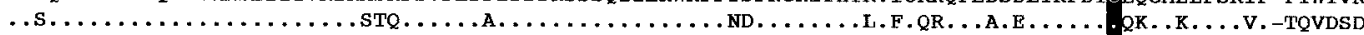

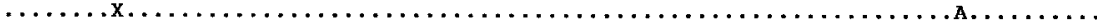

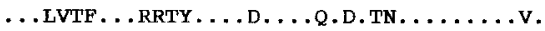
L FWER A . . E . FEI

....... . THLDSE

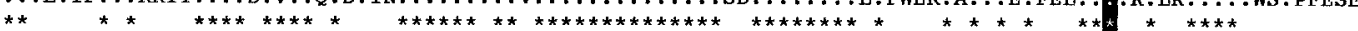

MSRSGTTQINPPRG-KVCACPKTDNQLKKEQEETEYRKTFENYLHNEVFESRPTRRRFSVGVANATLEPNFLTAAPSFPFGSTTASPDDDDKDDEGSKVE

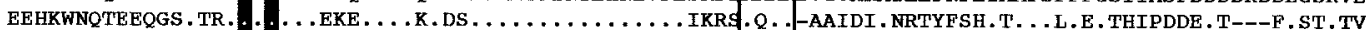

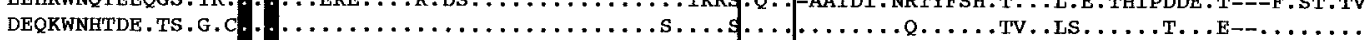

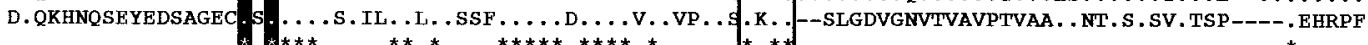

LKVFSKESKVISNLHHFTSYKIEIMACNHVTDIKRCSMATYVSARTMPEERADDI PGHVTHE IVTAEPPYVLIKWNAPRSPNGLI ILYEVFYRKVGDTEV

HTTCVSRPAYLKTGGTKLSLVQPGNYSVRVRATSLAGNGSFTETTYFFMPNPDP-_-GL IW TVIGPVFCFILLLFVGGGAFWI 7 KKRQTEGPTGPLIASS

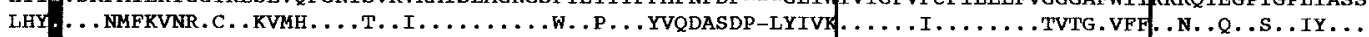

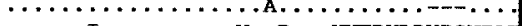

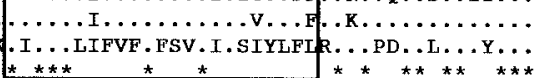

IIR-2

Turbot

Human

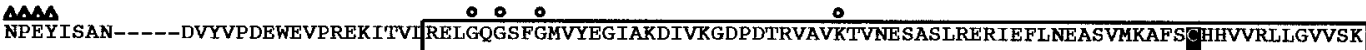

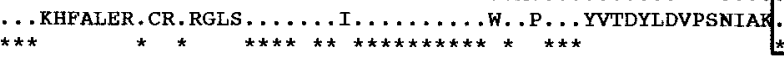

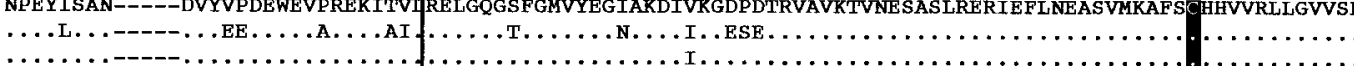

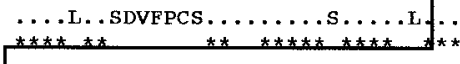

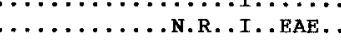

AQPTLVVMELMTHGDLKSYLRNLRPDSENNPTGRPPPTLKEM IQMAAE TADGMAYLNAKKHVHRDLAARNCMVAEDYTVKIGDFGMTRDIYETDYYRKGG

fIR-2

Turbot

Human

fIR-1

fIR-2

Turbot Human

$$
\begin{gathered}
\mathrm{AQP} \\
\mathrm{G} . . \\
\ldots \\
\mathrm{G} . \\
* * \\
\mathrm{KGL} \\
\cdots \\
\cdots \\
\cdots \\
\ldots \star
\end{gathered}
$$

KGLLPVRWMAPEST,KDGVFTAHSDCWSFGVVLWEISTLAEQPYQGLSNEQVLKFVMDGGYLDRPE NCPERMHNLMQMCWQYNPKMRPMEHEI IEMLREDL

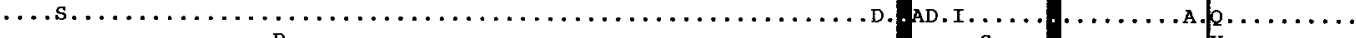

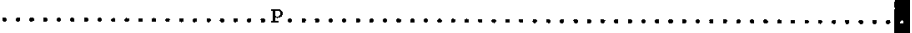

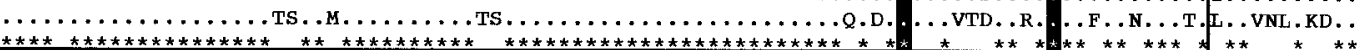

fIR-1

fIR-2

Turbot

HPS FQEVSFFYSEENKVPETEEFDLDLDNMES I PLDPSSYSQREESLGRDSGPSVALRG-NYEEHVPYTHMNGGKKNGRILSLPRSSPS

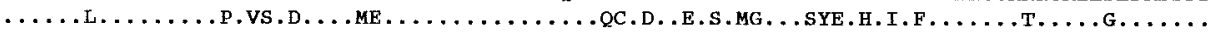

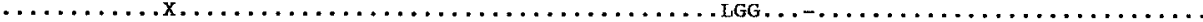

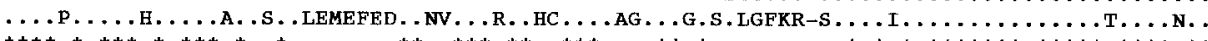


(b) fIGF-IR-1 IIGF-IR Turbot Human

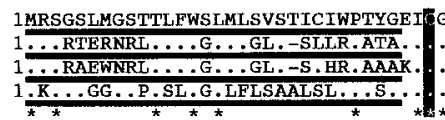

TVVEGYLQILLINDKTN-NIBQEVFRSLSFPKLTIITTDYLLLFRVSGL

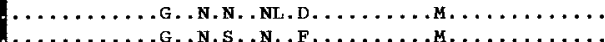

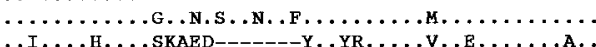

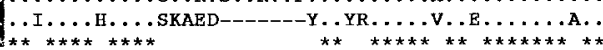
........ YOQL......

IIGF-IR-1 f IGF-IR-2 Turbot Human

DSLSMLFPNLSIIRGRQL FYNYALVIYEMTSLKDIGLYNLKNITRGATR IEKNPELTYLDSVDWSLIMDAEFNNIINGNKKAKE TDNVCPGTMEDNPLCK YLDSVUSUIMDAE

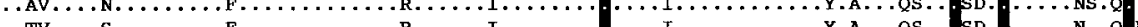

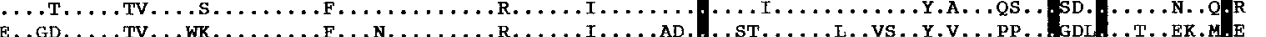

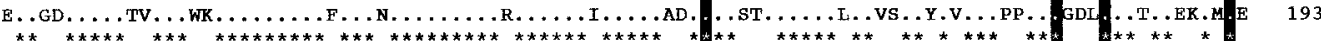

IIGF-IR-1 fIGF-IR-2 Turbot Human

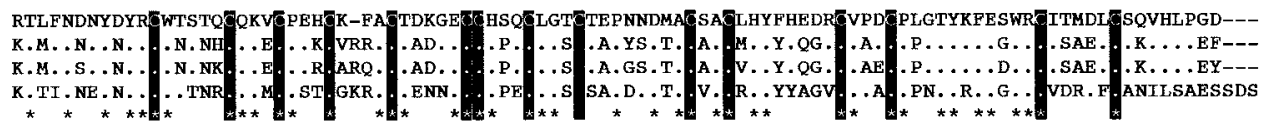
IIGF-IR-1 fIGF-IR-2 Turbot PQFVIHGGETMHD FPSGFTRNETNRMFCSACNGL TDKVCTPP---IIDSVDAAQSLKDCTVIEGNLDINIRRGNNIASELESFMGLIQTVKGYVKIRHS

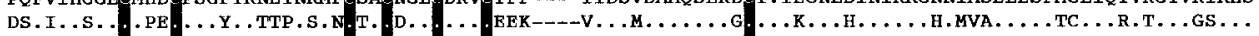

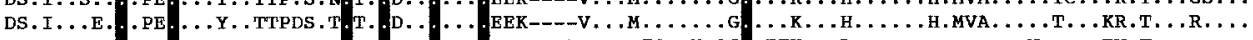

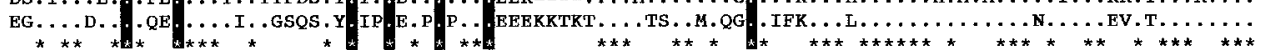
fIGF-IR-1 IIGF-IR-2 Turbot Human

HALGSLSFLKSLHYINGQELIDNMYSFSAINNQHLQYLWDWSQHNLTIRAGRLFFRRNPKLCHPE IHTHWEKTKITVKPEEG--DFRNNGDRAS TESHTL

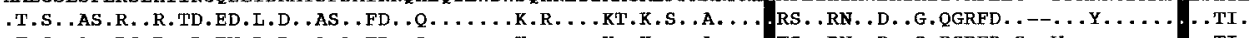

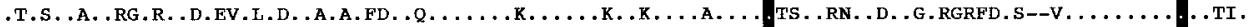

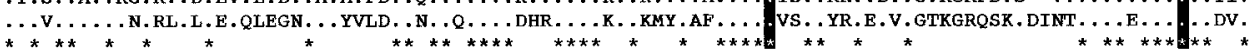

fIGF-IR-1 fIGF-IR-2

Turbot

Human

fIGF-IR-1 IIGF-IR-2 Turbot Human

fIGF-IR-1 fIGF $-I R-2$ Turbot Human

fIGF-IR-1 fIGF-IR-? Turbot Human

f IGF-IR-1 f IGF-IR-2 Turbot Human

fIGF-IR-1 f I GF -IR-2 Turbot Buman

fIGF-IR-1 FIGF-IR-2 Turbot Human

f IGF-IR-1 fIGP-IR-2 Turbot Human

fIGE-IR-1 fIGF-IR-2 Turbot Human

f IGF-IR-1 fIGF-IR-2 Turbot Buman

PFKTNETTSHTIRLTWDRYQPPDFGDLISFIVYFKESPFQNTTEFDGQDGGGSNSWHMVDVDLPQDKTSEPNVSLPHEKPWTQYAISVKAITLQVED-KH

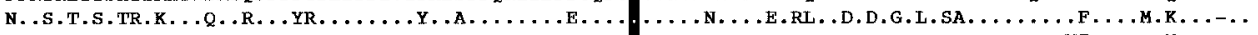

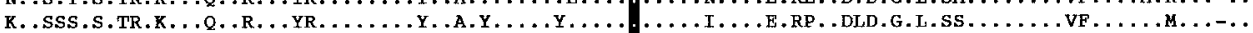

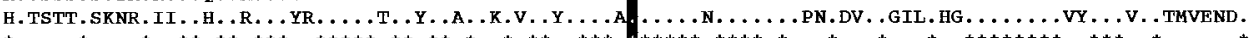

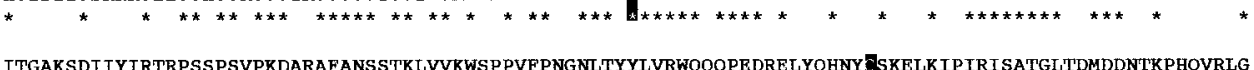
ITGAKSDIIYIRTRPSSPSVPKDARAFANS STKLVVKWSP PVFPGNLTYYLVRWQQQPEDRELYQHNY FSKELK IPIRI SATGLTDMDDNTKPHQVRLG

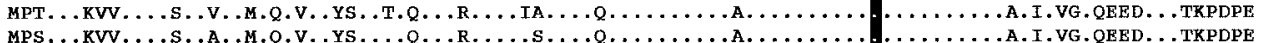

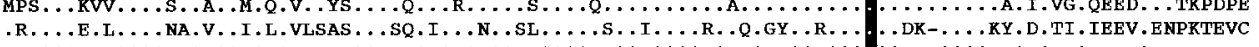

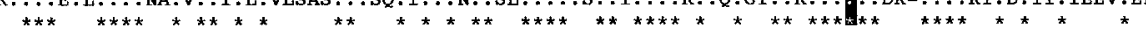

GGREGPH VVAED-AEEKDREKDDRVFLKTFENFLHNAIVLPRPPD RRRPPVFGVANDTLFHDSAGKGNTTLGPGNSTDGVP----_--P_--IKEYPFME

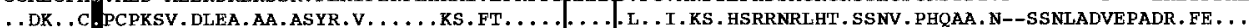

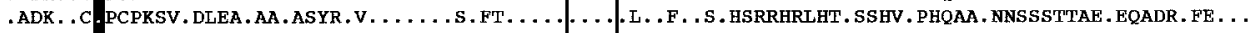

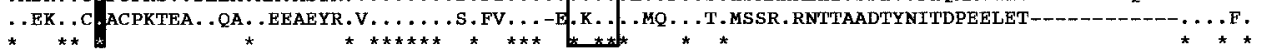
DKSSAEYLDIPN-LQPFTVYREDIHACNEEVGR--CSAGAFVFSRTKPAVKADDIPGKVIYERSDKVEGSVVLHWPE PIMPNGLTILMYE IKFRLGTEPEK

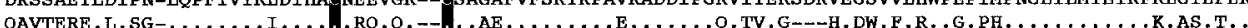

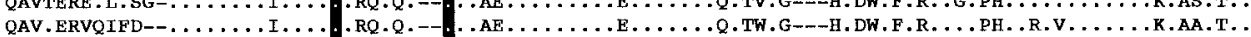

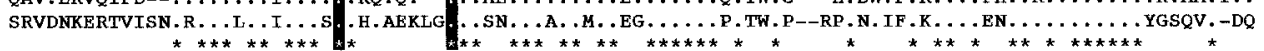

HECVSRQHYRE HRGARLTNLSSGNYSARVRATSLAGNGSWTESVFFYVPPPKRDDGVAFY GVIIIPIIATLLIASLTTILFFVNKKRNSDRLGNGVLYAS

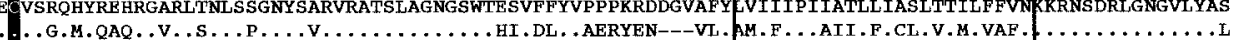

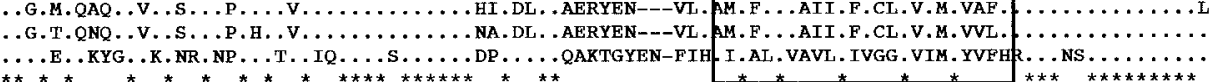

EMSFFYSEENKPPDTEELDMEVEN-MENIPLDPASTRQPSAVAAPSSGCTGGTPPPSAQQLSPMQGPSTPLLGPVSPSSSGPVASALASPGQALDKHSGH 1371 .V. . . . AD . . . SEEQQVHLDKMDNI.DV.A.QP.ST. .QQAQV.QQTPPSPSSEAPPAPSLSPSS . .S.CTSTAAMDKQASGQ-QA. NGLSGPSLAA.S 1377 DS ......AD ...V.DPQVHQDKMDSVDDV....P.ST..QQSPV.QQTPPPPSSEAPPAPSISPSS ..S.CTSTAAMDKQASG--.SGNGLSGPSHAA.S 1377 .V. .Y........EP....L.P.....SV . . . SASS--.SLPL. DRHSG-$\star \star * \star * *$ 
The membranes were prehybridized with yeast RNA $(200 \mu \mathrm{g} / \mathrm{ml})$ at $42{ }^{\circ} \mathrm{C}$ for $2 \mathrm{~h}$ and then hybridized with radiolabelled DNA fragments derived from $5^{\prime}$ - or $3^{\prime}$-noncoding regions of each IR and IGF-IR cDNAs (Fig. 1) in $50 \%$ formamide, $6 \times \mathrm{SSPE}$ and $0 \cdot 1 \%$ SDS at $42{ }^{\circ} \mathrm{C}$ for $16 \mathrm{~h}$. After washing twice with $2 \times \mathrm{SSC}$ containing $0 \cdot 1 \%$ SDS at $60{ }^{\circ} \mathrm{C}$ for $30 \mathrm{~min}$, the membranes were subjected to autoradiography for 14 days at $-80{ }^{\circ} \mathrm{C}$.

\section{Results}

cDNA cloning and characterization of the deduced amino acid sequences for fIRs and fIGF-IRs

Two fIR cDNA clones, fIR-1 and fIR-2, were isolated from the liver cDNA library, and two flGF-IR cDNA clones, flGF-IR-1 and flGF-IR-2, were obtained from the kidney cDNA library. Figure 1 shows schematic representations of the structures of these four cDNA clones. The flR-1, flR-2, flGF-IR-1 and flGF-IR-2 cDNAs contained open reading frames (ORFs) encoding proteins comprising 1369, 1368, 1412 and 1418 amino acid residues respectively. The deduced amino acid sequences are shown in Fig. 2, compared with those of human and turbot IRs and IGF-IRs. A potential proteolytic cleavaging sequence, $\mathrm{R}-\mathrm{X}-\mathrm{R}-\mathrm{R}$, was conserved at the putative junctions of $\alpha$ - and $\beta$-subunits of all these receptors. The cysteine-rich domains in the $\alpha$-subunits of both flRs contained 26 cysteine residues whereas both flGF-IRs contained 24 cysteine residues, as was observed in $\alpha$-subunits of mammalian IRs and IGF-IRs respectively. In the $\beta$-subunits of flRs and flGF-IRs, a putative IRS-I-binding site, NPEY, a potential ATP-binding site, G-X-G-X-X-G-21X-K (Hanks et al. 1988) and an autophosphorylation site, YETDYY were well conserved in their tyrosine kinase domains. As compared with human IGF-I-R, large insertions were observed in the C-termini of flGF-IRs and turbot IGF-IR (Ullrich et al. 1986, Eliès et al. 1999).

As shown in Table 2, both flRs showed higher sequence identities with human IR than with human IGF-IR, and both flGF-IRs exhibited higher sequence identities with human IGF-IR than with human IR. Turbot IR showed a higher sequence identity with fIR-1 $(91 \cdot 7 \%)$ than with flR-2 (73.2\%), and turbot IGF-IR showed a higher sequence identity with fIGF-IR-2 $(90 \cdot 5 \%)$ than with flGF-IR-1 (66.8\%), suggesting that
Table 2 Amino acid sequence similarity between human, turbot and flounder IRs and IGF-IRs

\begin{tabular}{|c|c|c|c|c|c|}
\hline & Receptor & fIR-1 & fIR-2 & fIGF-IR-1 & fIGF-IR-2 \\
\hline Human & $\begin{array}{l}\text { IR } \\
\text { IGF-IR }\end{array}$ & $\begin{array}{l}65 \cdot 6 \\
55 \cdot 4\end{array}$ & $\begin{array}{l}67 \cdot 5 \\
56 \cdot 9\end{array}$ & $\begin{array}{l}52 \cdot 3 \\
63 \cdot 6\end{array}$ & $\begin{array}{l}51 \cdot 8 \\
63 \cdot 0\end{array}$ \\
\hline Turbot & $\begin{array}{l}I^{*} \\
\text { IGF-IR }\end{array}$ & $\begin{array}{l}91 \cdot 7 \\
51 \cdot 1\end{array}$ & $\begin{array}{l}74 \cdot 0 \\
51 \cdot 0\end{array}$ & $\begin{array}{l}50 \cdot 6 \\
66 \cdot 8\end{array}$ & $\begin{array}{l}50 \cdot 7 \\
90 \cdot 5\end{array}$ \\
\hline Flounder & $\begin{array}{l}\text { fIR-1 } \\
\text { fIR-2 } \\
\text { fIGF-IR-1 } \\
\text { flGF-IR-2 }\end{array}$ & $\begin{array}{l}100 \\
73 \cdot 2 \\
52 \cdot 1 \\
51 \cdot 3\end{array}$ & $\begin{array}{l}73 \cdot 2 \\
100 \\
51 \cdot 0 \\
51 \cdot 4\end{array}$ & $\begin{array}{l}52 \cdot 1 \\
51 \cdot 0 \\
100 \\
67 \cdot 5\end{array}$ & $\begin{array}{l}51 \cdot 3 \\
51 \cdot 4 \\
67 \cdot 5 \\
100\end{array}$ \\
\hline
\end{tabular}

*Because a lack is seen in turbot IR N-terminal end, fIR-1, fIR-2, fIGF-IR-1 and fIGF-IR-2 comparisons with turbot IR were performed using 1369/1245, $1368 / 1245,1412 / 1245$ and 1418/1245 amino acids respectively.

flR-1 and flGF-IR-2 are the flounder counterparts for the reported turbot IR and IGF-IR respectively. In phylogenetic analysis, the evolutional positions of flR-1 and fIR-2 were located in the IR groups, whereas flGF-IR-1 and flGF-IR-2 belonged to the IGF-IR groups (Fig. 3).

Northern blot analyses of transcripts for fIRs and fIGF-IRs in flounder heart

Figure 4 shows the results of Northern blot analyses of mRNAs for flRs and flGF-IRs in the heart, where abundant expression of all the four mRNAs was observed by the RNase protection assay. One major transcript band of $13 \mathrm{~kb}$ was detected for flR-1, and one major mRNA band of $8 \mathrm{~kb}$ was observed for flR-2. Two major bands of 11 and $9 \mathrm{~kb}$ were detected for flGF-IR-1 transcripts, and one major band of $11 \mathrm{~kb}$ and one minor band of $0.9 \mathrm{~kb}$ were observed as flGF-IR-2 transcripts.

\section{Tissue distribution of IR and IGF-IR $m R N A s$ in flounder}

The distribution of fIR-1, flR-2, flGF-IR-1 and flGFIR-2 mRNAs in the flounder tissues were examined by the RNase protection assay (Fig. 5). flR-1 mRNA was clearly detected in the liver, kidney, brain, spleen, testis, heart, gill arch and ovary, and faintly in the stomach, intestine, skeletal muscle and eye. The highest expression was observed in the heart. Similar results were obtained in fIR-2 mRNA analysis except for its abundant expression in the gill arch. flGF-IR-1 mRNA was clearly detected in

Figure 2 (a) Comparison of amino acid sequences of fIR-1 and fIR-2 with turbot and human IRs. (b) Comparison of amino acid sequences of flGF-IR-1 and flGF-IR-2 with turbot and human IGF-IRs. Turbot and human sequences were obtained from the GenBank Database. IR; turbot (AJ224994), human (X02160), IGF-IR; turbot (AJ224993), human (M24599). Asterisks indicate identical amino acids. Gaps were introduced to maximize the matching. The signal sequences are heavily underlined, cysteine residues are shown by black boxes. Boxed regions indicate, in order, the putative precursor processing site, the transmembrane domain and the tyrosine kinase domain. The arrowheads indicate potential residues involved in IRS-1/IRS-2 binding. The open circles indicate important ATP binding and black circles indicate essential amino acids at the receptor autophosphorylation site. A black arrowhead indicates a position where insertion of exon 11 can generate different isoforms of the mammalian IR. 


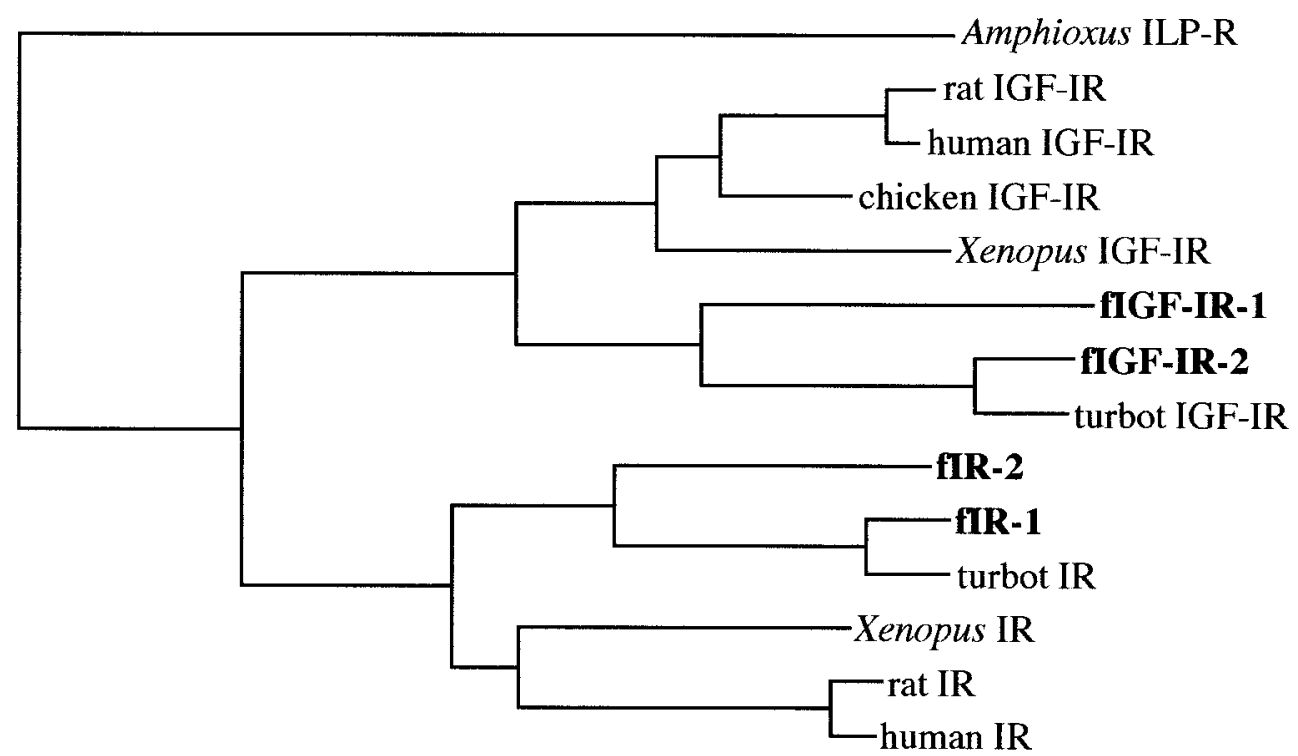

Figure 3 Evolutionary tree of the IR/IGF-IR family members. The tree was constructed using a distance matrix based on protein sequence and the neighbour-joining method of Saitou \& Nei (1987). The amino acid sequences were aligned with the GENETYX software (Tokyo, Japan). These sequences were obtained from the GenBank Database. IR; human (X02160), rat (M29014), Xenopus (AJ132556), turbot (AJ224994). IGF-IR; human (M24599), rat (L29232), chicken (CAA11144), Xenopus (M64660), turbot (AJ224993) and Amphioxus insulin-like peptide receptor (S83394).

the testis, heart and gill arch, but weakly in other tissues. flGF-IR-2 mRNA was highly expressed in the testis, heart, gill arch and ovary, and in other tissues the expressions were lower. After prolonged exposure, however, all four mRNAs were clearly detected for all the tissues tested.

\section{Discussion}

In the present study, a complete set of four full-length cDNAs for distinct flR-1, flR-2, flGF-IR-1 and flGFIR-2 were cloned and characterized. In human, a 28 amino acid open reading frame (ORF) has been identified in $5^{\prime}$-untranslated region (UTRs) of IGF-IR mRNA but the function has not yet been clarified. Two ORFs of 60 and 37 amino acids were observed in turbot (Eliès et al. 1999). In this study, ORFs of 36 and 35 amino acids were found in the $5^{\prime}$-UTR of fIGF-IR-1 and fIGF-IR-2 respectively. The short ORF was found before the polyadenylation signal which is located $250 \mathrm{bp}$ upstream of the flGF-IR-2 translation initiation codon (Fig. 6). Actually, a short transcript of $0.9 \mathrm{~kb}$, which may be inferred to be derived from a short ORF in the $5^{\prime}$-UTR of flGF-IR-2, was detected by Northern blot analysis using a probe prepared from the $5^{\prime}$-non-coding region of flGF-IR-2 cDNA. However, the ORF of 36 amino acid residues in the $5^{\prime}$-non-coding region of flGF-IR-1 cDNA had no polyadenylation signal (data not shown), resulting in the absence of the $0.9 \mathrm{~kb}$ transcript expression (Fig. 6). A recent report also showed the translation of two putative unrelated proteins (leptin receptor and $\mathrm{OB}$ receptor generelated protein) from alternatively spliced mRNAs which were transcribed under the control of the same promoter (Bailleul et al. 1997).

All the amino acid sequences deduced from the cDNA clones contained characteristic features of IR and IGF-IR. However, the varied primary structures of these four receptors suggest that similar but complex signal transductions may occur when the ligands, insulin and IGF-I, bind to them. Considering the report that the Japanese flounder is diploid (Tabata 1991) and the present findings that sequences of the $5^{\prime}$ - and $3^{\prime}$-non-coding regions are less homologous than those of the coding regions between flR-1 and flR-2 or between flGF-IR-1 and flGF-IR-2 (44-48\% identical nucleotide sequences as presented in DNA databases referred to in Fig. 1 legend), these four receptors may be the products of four different genes. On the other hand, molecules of insulin (Andoh \& Nagasawa 1998) and IGF-I (Tanaka et al. 1998) have been reported to be produced by a single gene in Japanese flounder. The amino acid sequences of flR-1 and flR-2 are more homologous to that of human IR than to that of human IGF-IR, and those of fIGF-IR-1 and fIGF-IR-2 are more similar to that of human IGF-IR than human IR. Furthermore, the phylogenetic analysis showed that flRs and flGF-IRs were clearly localized in the IR branch and IGF-IR branch respectively in the evolutionary tree 

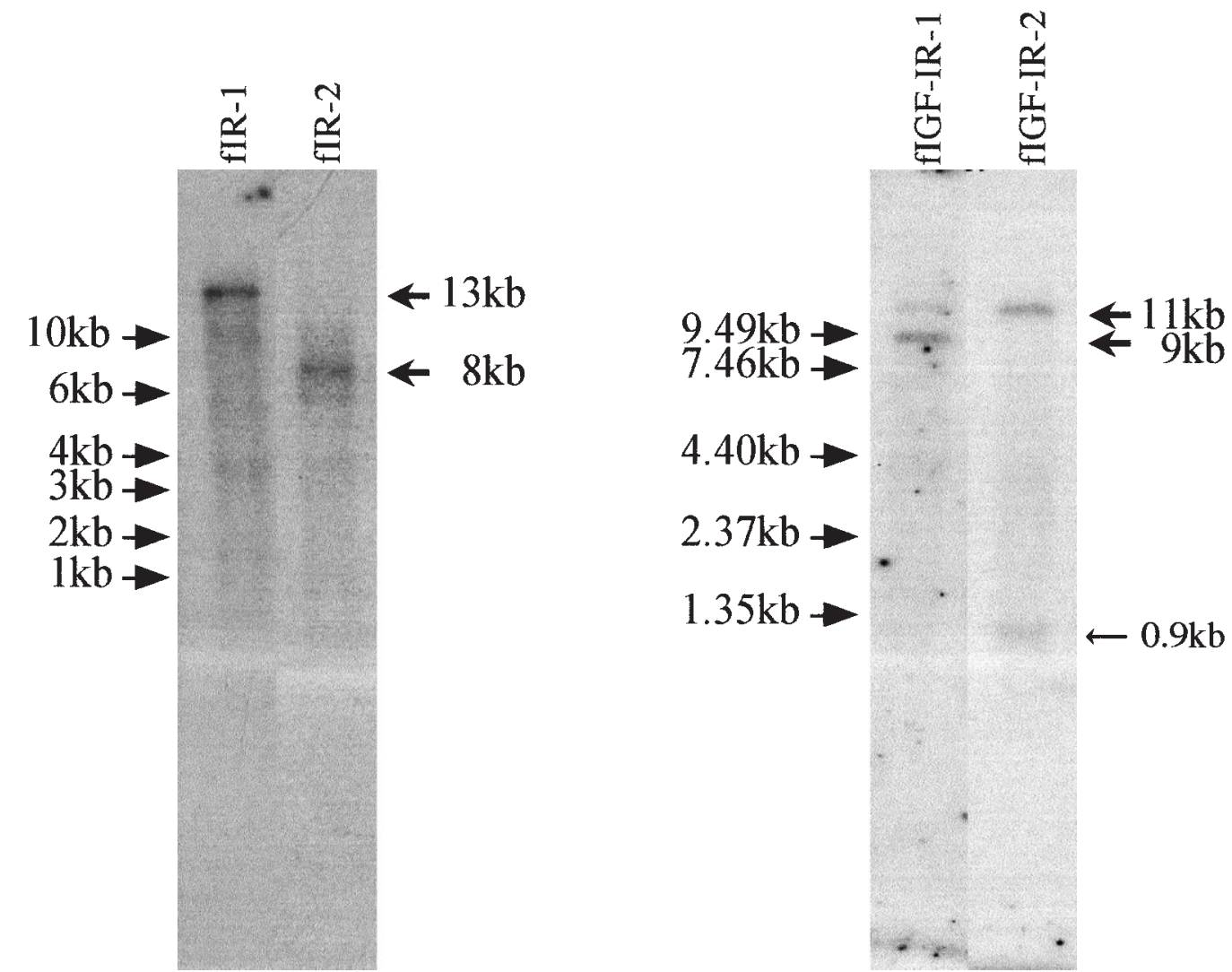

Figure 4 Northern blot analysis of fIR and fIGF-IR mRNAs. Poly(A)+ RNA (4.5 $\mu \mathrm{g})$ from flounder heart was electrophoresed on a $1 \%$ agarose-formaldehyde gel, transferred to a nylon membrane, and hybridized with radiolabelled cDNA probes corresponding to the $3^{\prime}$-non-coding regions of fIR-1 or fIR-2 and to the $5^{\prime}$-non-coding regions of flGF-IR-1 or flGF-IR-2 cDNAs shown in Fig. 1. Positions of RNA size markers are shown at the left.

(Fig. 3). These results strongly suggest that fIR-1 and flR-2 are receptors for insulin and that flGF-IR-1 and flGF-IR-2 are receptors for IGF-I.

Relatively abundant expressions of fIR-1 and fIR-2 mRNAs were observed at the heart, gill arch and liver. flGF-IR-1 and flGF-IR-2 mRNAs showed similar expression profiles to each other. The expression profiles of IR mRNAs are, however, distinctly different from those of IGF-IR mRNAs. Both flGF-IRs were abundantly expressed in the heart, gill arch and testis. Abundant expression was also observed in the ovary for flGF-IR-2, but not for flGF-IR-1. Varied distributions of flR-1, fIR-2, flGF-IR-1 and flGF-IR-2 in diverse flounder tissues would support a wide variety of insulin and IGF-I actions. These gene duplications may have enhanced the evolution of teleosts (Amores et al. 1998, Pennisi 2001).

In mammals, skeletal muscle is the principal target tissue for insulin action, and the one where insulin predominantly acts to control the glucose level. IGF-I has also been reported to stimulate glucose uptake and its metabolism and protein synthesis in mammalian skeletal muscle (Dardevet et al. 1994). Infusion of IGF-I in humans stimulated whole-body glucose uptake, which was similar to the response to insulin (Boulware et al. 1992). However, for flRs and flGF-IRs, very low levels of mRNA expression were observed in the skeletal muscle. Similar results were obtained with rainbow trout IR and IGF-IR (Greene \& Chen 1999a,b) and turbot IR (Eliès et al. 1999). In rainbow trout, it has also been reported that glucose uptake and metabolism are higher in the heart than in skeletal muscle (West et al. 1993). Greene \& Chen (1999b) have suggested that a potential mechanism for this discrepancy may involve IGF-I binding to cell-surface IGF-binding proteins in teleost muscle membrane.

The mechanical working of the heart requires a constant turnover of protein synthesis, as observed in rat heart. It has been demonstrated that the cardiac protein synthesis is stimulated by IGF-I and insulin in the rat (Fuller et al. 1992). As for fishes, both insulin and IGF-I bind more abundantly to heart than to skeletal muscle in brown trout or carp (Párrizas et al. 1995). The present study shows high-level expression of fIR and fIGF-IR mRNAs in the heart but much lower levels in the skeletal muscle. The cellular expression of IRs and IGF-IRs in flounder heart 


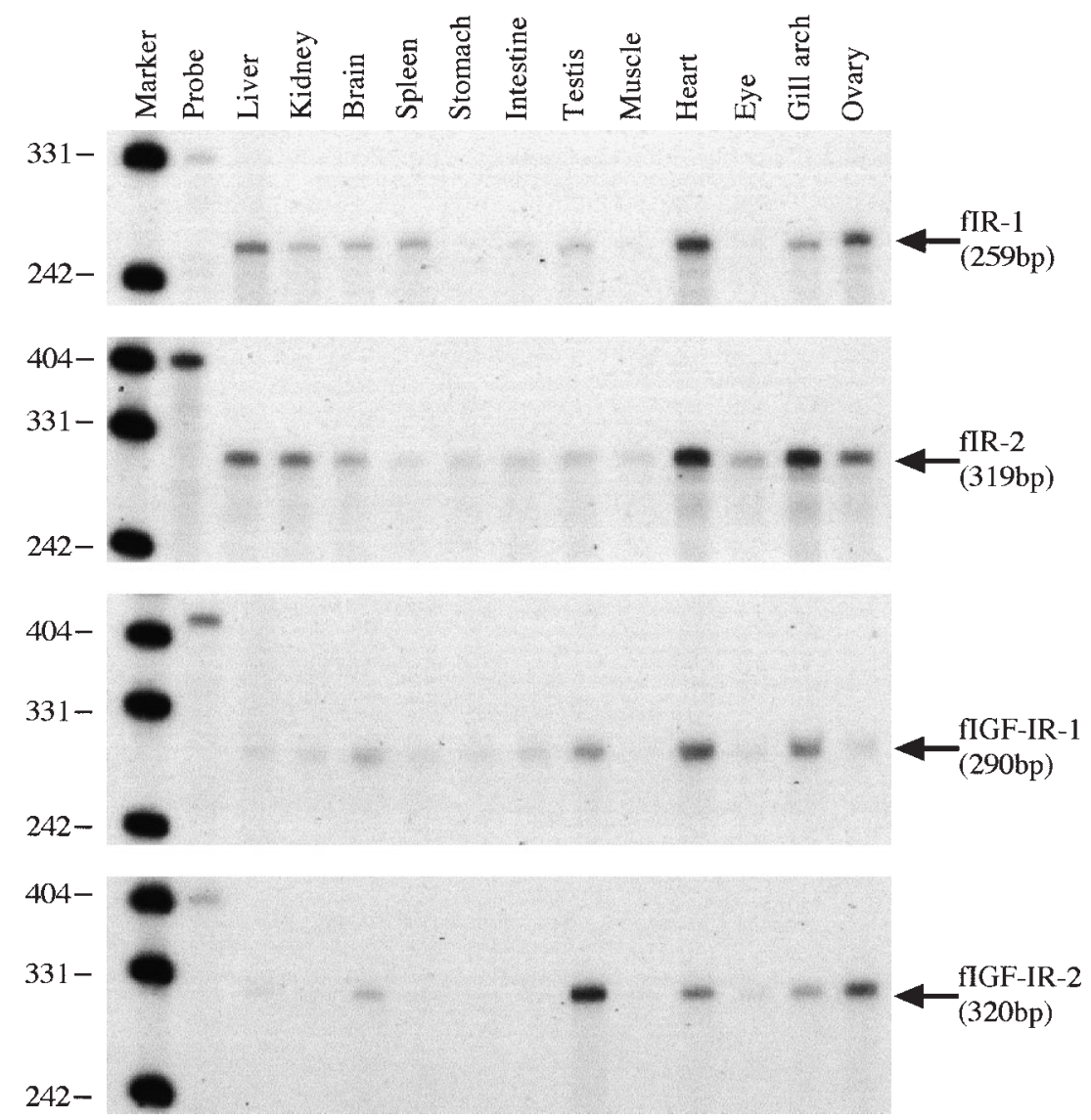

Figure 5 Expression profiles of fIR-1, fIR-2, fIGF-IR-1 and fIGF-IR-2 mRNAs in flounder tissues analysed by the RNase protection assay. Total RNAs $(20 \mu \mathrm{g})$ from flounder tissues were subjected to the assay with antisense RNA probes corresponding to the

$3^{\prime}$-non-coding region in fIR- 1 and fIGF-IR-1 mRNA, to the extracellular region of $\beta$-subunit in fIR-2 mRNA and to the $5^{\prime}$-coding region in flGF-IR-2 shown in Fig. 1. An Mspl digest of pUC19 plasmid DNA was used as a size marker. These are representative autoradiograms for each male and female from three independent experiments.

TGCATTCATCCAGCGACGCGACCCGTTCACGCTGCGTGTGCATCCACGGAGAGGCATAATATCAGAGGAGCTGAGCGACC 80 CCGGAGCAACAAGGTCAAATCCTCCGGTTGTTCCCCCCCCCCTCGTTGTCGCGAAGGTGCATTACAGCCACCACAACAAC 160 GCGGTGCGTGTGAGCATGATGAGCGGCTGAGGAGGAGGCTGCTGCGGTCTGAAACCAGATTTGATCCTGGATATTTCGAC 240 ACAGACGTCGTGCCGTTCGCTTACACGGGCTGTGTTTGTGTTTGATATGATATCGTGTGCTCCTCGCCGCCTCTTCCCAT 320 CCCGTTCTTGAAGGGGGGGGTGGTGTCTCACCCATTCTCTGCCTCCCGAGGATCCTCCGGCAGCGGGACGTTGAGCGTTT 400 TTTCTTCCAGCTATGGAGCGTGAAGATGCGGATTACAGAGGAATCCCCGCCGCTGCTGTAGCCGCATTGTACACACATTC 480 $\begin{array}{llllllllllllllllllllllll}M & E & R & E & D & A & D & Y & R & G & I & P & A & A & A & V & A & A & L & Y & T & H & S & 23\end{array}$ GACACGGCGCAGTTTTCGGCAGGAACAAGCAGAACTATGAATACGCATTTTCAGCCTAGAGGAATAAATCGGTGATTATT 560 $\begin{array}{llllllllllllll}T & R & R & S & F & R & Q & E & Q & A & E & L & *\end{array}$ TTAGCTTTTAGCTCCTTTAGCCGGCTAACTGCTAAAAGGTGCTGGCTGGGGGATTGAAAAGCGATTTAATAATTCCGGCC 720 AGGCTTTGCCGAGCCTTTCCCCCCCTCAACATATTTATTTACAGGGTCTGGGGGGATTCACTTATTCCAGGA

Figure 6 Nucleotide sequence of the 5'-untranslated region (UTR) of flGF-IR-2 cDNA. The 5'-UTR of cDNA sequence (above) of fIGF-IR-2 and the predicted amino acid sequence (below) are shown. The potential polyadenylation signal is underlined and the arrow indicates the fIGF-IR-2 translation initiation codon. ${ }^{*}$ Stop codon. 
appears to be overlapping. The tyrosine kinase activity was stimulated by insulin and IGF-I in a dose-dependent manner in cardiac receptor preparations of carp and trout (Gutierréz et al. 1995). It may be predicted that a fraction of the flRs and flGF-IRs in heart exist as hybrids, heterodimers of IRs and IGF-IRs, because hybrid receptors are widely distributed in mammalian tissues including the heart (Elaine et al. 1997). Finally, the structure of the insulin-like peptide deduced from its cDNA of the Amphioxus, suggests a hybrid molecule with characteristics of both peptides, insulin and IGF-I (Chan et al. 1990). The recent report of the existence of an insulin-like peptide receptor in the primitive chordate Amphioxus which shares features of both IRs and IGF-IRs clearly suggests the common origin of these two receptor species in primitive chordates (Pashmforoush et al. 1996).

In the flounder liver, fIR mRNAs were expressed at high levels but flGF-IR mRNAs were at low levels. The expression pattern of IGF-IR mRNA, low in the liver and high in the gill, has also been reported in gilthead seabream (Perrot et al. 1999, 2000) and salmon (Chan et al. 1997). The role of the liver in glucose tolerance is not so clear in fish as it is in mammals. The action of IGF-I on the gill of fishes has been suggested to be for osmoregulation (McCormick et al. 1991, Sakamoto \& Hirano 1993). flGF-IR mRNAs were also found in the gill, suggesting an osmoregulatory action of IGF-I in that organ. Diverse distribution of IGF-IR-1 and IGF-IR-2 mRNAs in flounder tissues suggests, however, that IGF-I is essentially involved in skeletal growth of the teleost.

In conclusion, we have demonstrated the existence of two distinct IRs (fIR-1 and flR-2) and two distinct IGF-IRs (flGF-IR-1 and flGF-IR-2) in the flounder. Northern blot analyses revealed that the major transcripts for fIR-1, fIR-2, fIGF-IR-1 and fIGF-IR-2 were approximately $13,8,9$ and $11 \mathrm{~kb}$ respectively. RNase protection assays showed that the flR and flGF-IR transcripts were present in a wide range of tissues, with the highest levels in the heart.

\section{Acknowledgement}

This study was supported by a grant (Development of Fundamental Technologies for Effective Genetic Improvement of Aquatic Organisms) from the Ministry of Agriculture, Forestry and Fisheries of Japan.

\section{References}

Amores A, Force A, Yan YL, Joly L, Amemiya C, Fritz A, Ho RK, Langeland J, Prince V \& Postlethwait JH 1998 Zebrafish hox clusters and vertebrate genome evolution. Science 282 1711-1714.

Andoh T \& Nagasawa H 1998 Two molecular forms of insulin from barfin flounder, Verasper moseri, are derived from a single gene. Zoological Science 15 931-937.
Bailleul B, Akerblom I \& Strosberg AD 1997 The leptin receptor promoter controls expression of a second distinct protein. Nucleic Acids Research 25 2752-2758.

Boulware SD, Tamborlane WV, Matthews LS \& Sherwin RS 1992 Diverse effects of insulin-like growth factor I on glucose, lipid, and amino acid metabolism. American Journal of Physiology 262 E130-E133.

Chan SJ, Cao Q-P \& Steiner DF 1990 Evolution of insulin superfamily: cloning of a hybrid insulin/insulin-like growth factor cDNA from Amphioxus. PNAS 87 9319-9323.

Chan SJ, Plisetskaya EM, Urbinati E, Jin Y \& Steiner DF 1997 Expression of multiple insulin and insulin-like growth factor receptor genes in salmon gill cartilage. PNAS 94 12446-12451.

Cheatham B \& Kahn CR 1995 Insulin action and the insulin signalling network. Endocrine Reviews 16 117-142.

Cheng CM \& Chen TT 1995 Synergism of GH and IGF-I in stimulation of sulphate uptake by teleostean branchial cartilage in vitro. Journal of Endocrinology 147 67-73.

Chomczynski P \& Sacchi N 1987 Single-step method of RNA isolation by acid guanidinium thiocyanate-phenol-chloroform extraction. Analytical Biochemistry 162 156-159.

Dardevet D, Sornet C, Attaix D, Baracos VE \& Grizard J 1994 Insulin-like growth factor-1 and insulin resistance in skeletal muscles of adult and old rats. Endocrinology 134 1475-1484.

Drakenberg K, Sara VR, Falkmer S, Gammeltoft S, Maake C \& Reinecke M 1993 Identification of IGF-I receptors in primitive vertebrates. Regulatory Peptides 43 73-81.

Ebina Y, Ellis L, Jarnagin K, Edery M, Graf L, Clauser E, Ou JH, Masiarz F, Kan YW, Goldfine ID et al. 1985 The human insulin receptor cDNA: the structural basis for hormone-activated transmembrane signalling. Cell $\mathbf{4 0}$ 747-758.

Elaine MB, Barbara TN, Maria AS, Stephen RO, Amanda CH \& Kenneth S 1997 Insulin receptor/IGF-I receptor hybrid are widely distributed in mammalian tissues: quantification of individual receptor species by selective immunoprecipitation and immunoblotting. Biochemical Journal 327 209-215.

Eliès G, Duval H, Bonnec G, Wolff J, Boeuf G \& Boujard D 1999 Insulin and insulin-like growth factor-1 receptors in an evoluted fish, the turbot: cDNA cloning and mRNA expression. Molecular and Cellular Endocrinology 158 173-185.

Fuller SJ, Mynett JR \& Sugden PH 1992 Stimulation of cardiac protein synthesis by insulin-like growth factors. Biochemical Journal $28285-90$

Greene MW \& Chen TT 1999a Characterization of teleost insulin receptor family members. I. Developmental expression of insulin receptor messenger RNAs in rainbow trout. General and Comparative Endocrinology 115 254-269.

Greene MW \& Chen TT 1999b Characterization of teleost insulin receptor family members. II. Developmental expression of insulin-like growth factor type I receptor messenger RNAs in rainbow trout. General and Comparative Endocrinology 115 270-281.

Gutierréz J, Párrizas M, Maestro MA, Navarro I \& Plisetskaya EM 1995 Insulin and IGF-I binding and tyrosine kinase activity in fish heart. Journal of Endocrinology 146 35-44.

Hanks SK, Quinn AM \& Hunter T 1988 The protein kinase family: conserved features and deduced phylogeny of the catalytic domains. Science 241 42-52.

Kelley KM, Gray ES, Siharath K, Nicoll CS \& Bern HA 1993 Experimental diabetes mellitus in a teleost fish. II. Roles of insulin, growth hormone $(\mathrm{GH})$, insulin-like growth factor-I, and hepatic $\mathrm{GH}$ receptors in diabetic growth inhibition in the goby, Gillichthys mirabilis. Endocrinology 132 2696-2702.

LeRoith D, Werner H, Beitner-Johnson D \& Roberts CT Jr 1995 Molecular and cellular aspects of the insulin-like growth factor I receptor. Endocrine Reviews 16 143-163.

Maestro MA, Mendez E, Párrizas M \& Gutierréz J 1997 Characterization of insulin and insulin-like growth factor-I ovarian 
receptors during the reproductive cycle of carp (Cyprinus carpio). Biology of Reproduction 56 1126-1132.

McCormick SD, Sakamoto T, Hasegawa S \& Hirano T 1991 Osmoregulatory actions of insulin-like growth factor-I in rainbow trout (Oncorhynchus mykiss). Journal of Endocrinology 130 87-92.

Párrizas M, Maestro MA, Baños N, Navarro I, Planas J \& Gutierréz J 1995 Insulin/IGF-I binding ratio in skeletal and cardiac muscles of vertebrates: a phylogenetic approach. American Journal of Physiology 269 R1370-R1377.

Pashmforoush M, Chan SJ \& Steiner DF 1996 Structure and expression of the insulin-like peptide receptor from Amphioxus. Molecular Endocrinology 10 857-866.

Pennisi E 2001 Molecular evolution. Genome duplications: the stuff of evolution? Science 294 2458-2460.

Perrot V, Moiseeva EB, Gozes Y, Chan SJ, Ingleton P \& Funkenstein B 1999 Ontogeny of the insulin-like growth factor system (IGF-I, IGF-II, and IGF-IR) in gilthead seabream (Sparus aurata): expression and cellular localization. General and Comparative Endocrinology 116 445-460.

Perrot V, Moiseeva EB, Gozes Y, Chan SJ \& Funkenstein B 2000 Insulin-like growth factor receptors and their ligands in gonads of a hermaphroditic species, the gilthead seabream (Sparus aurata): expression and cellular localization. Biology of Reproduction $\mathbf{6 3}$ 229-241.

Saitou N \& Nei M 1987 The neighbor-joining method: a new method for reconstructing phylogenetic trees. Molecular Biology and Evolution 4 406-425.

Sakamoto T \& Hirano T 1993 Expression of insulin-like growth factor I gene in osmoregulatory organs during seawater adaptation of the salmonid fish: possible mode of osmoregulatory action of growth hormone. PNAS 90 1912-1916.
Sanger F, Nicklen S \& Coulson AR 1977 DNA sequencing with chain-terminating inhibitors. PNAS 74 5463-5467.

Tabata K 1991 Induction of gynogenetic diploid males and presumption of sex determination mechanisms in the hirame Paralichthys olivaceus. Bulletin of the Japanese Society of Scientific Fisheries 57 845-850.

Tanaka M, Taniguchi T, Yamamoto I, Sakaguchi K, Yoshizato H, Ohkubo T \& Nakashima K 1998 Gene and cDNA structures of flounder insulin-like growth factor-I (IGF- I): multiple mRNA species encode a single short mature IGF-I. DNA and Cell Biology 17 859-868.

Ullrich A, Bell JR, Chen EY, Herrera R, Petruzzelli LM, Dull TJ, Gray A, Coussens L, Liao YC, Tsubokawa M et al. 1985 Human insulin receptor and its relationship to the tyrosine kinase family of oncogenes. Nature 313 756-761.

Ullrich A, Gray A, Tam AW, Yang-Feng T, Tsubokawa M, Collins C, Henzel W, Le Bon T, Kathuria S, Chen E et al. 1986 Insulin-like growth factor I receptor primary structure: comparison with insulin receptor suggests structural determinants that define functional specificity. EMBO Journal 5 2503-2512.

West TG, Arthur PG, Suarez RK, Doll CJ \& Hochachka PW 1993 In vivo utilization of glucose by heart and locomotory muscles of exercising rainbow trout (Onchorhynchus mykiss). Journal of Experimental Biology 177 63-79.

Received in final form 22 January 2002 Accepted 5 February 2002 